\title{
SUMBER DAYA BERSAMA, KONTESTASI, HADIRNYA SPIRIT BERDESA : STUDI KASUS PENGELOLAAN TELAGA JONGE DESA PACAREJO, KABUPATEN GUNUNGKIDUL
}

\author{
Agustinus Sakro \\ Sekolah Tinggi Pembangunan Masyarakat Desa "APMD" Yogyakarta, Indonesia \\ Korespondensi Penulis: Sakroagustinus96@gmail.com
}

\begin{abstract}
ABSTRAK
Penelitian ini menjelaskan upaya pemerintah desa dalam memproteksi Telaga Jonge dan konflik akibat dari praktik privatisasi oleh Kelompok Sadar Wisata. Penelitian mengunakan pendekatan institusional dipandu mengunakan metode kualitatif dengan strategi studi kasus Pengelolaan Wisata Telaga Jonge Desa Pacarejo, Semanu Gunungkidul. Data primer dikumpulkan melalui observasi, dokumentasi, wawancara dengan sejumlah pelaku usaha, pemerintah desa, pengelola dan masyarakat setempat. Data sekunder diperoleh melalui buku, jurnal, dokumen, media online, dan foto. Hasil penelitian menemukan pengelolaan wisata Telaga Jonge terindikasi ada intervensi swasta. Pada saat yang sama negara dan desa absen. Sementara Kelompok Sadar Wisata memperoleh kuasa melalui program desa wisata. Malpraktik sengketa antara pemerintah desa, Pokdarwis dan masyarakat tidak terhindar. Hal ini terjadi karena, oleh dan dari kehadiran institusi berbasis masyarakat yang dikehendaki program. Menyikapi hal tersebut, pemerintah desa menempuh rekayasa sosial untuk memproteksi konflik dan mengembalikan Telaga Jonge menuju desa.
\end{abstract}

Kata Kunci: Desa, The Common, Program Desa Wisata dan Sengketa

\begin{abstract}
This study explains the efforts of the village government in protecting Telaga Jonge and the conflicts resulting from the privatization practice of the Tourism Awareness Group. The study used an institutional approach guided by using qualitative methods with a case study strategy of Jonge Lake Tourism Management in Pacarejo Village, Semanu Gunungkidul. Primary data were collected through observation, documentation, interviews with a number of business actors, village government, managers and local communities. Secondary data is obtained through books, journals, documents, online media and photos. The results of the study found that the management of Telaga Jonge tourism indicated that there was private intervention. At the same time the state and village were absent. Meanwhile, the Tourism Awareness Group gained power through the tourism village program. Malpractice disputes between the village government, Pokdarwis and the community are unavoidable. This happens because, by and from the presence of community-based institutions that the program wants. In response to this, the village government took social engineering to protect the conflict and returned Telaga Jonge to the village.
\end{abstract}


Keywords: Village, the Common, Tourism Village Program and Disputes

\section{Informasi Artikel}

Diterima: Oktober 2020, Disetujui: November 2020, Dipublikasikan: Desember 2020

DOI: https://doi.org/10.47431/governabilitas.v1i2.87

\section{PENDAHULUAN}

Undang-undang dasar Republik Indonesia Pasal 33 ayat (3) berbunyi Bumi dan air dan kekayaan alam yang terkandung di dalamnya dikuasai oleh negara dan dipergunakan untuk sebesar-besarnya kemakmuran rakyat. Pasal ini telah mengingatkan bahwa, keberadaan kekayaan alam diutamakan untuk kepentingan hajat orang banyak. Pertama pemerintah hadir untuk mengatur, mengelola dan merawat sumber daya alam. Hal ini bertujun untuk mendistribusikan keadilan kepada rakyat secara adil. Ini paralel dengan pembukaan Undang-Undang Dasar 1945 alinea kelima.

Pasca Undang-Undang No 6 Tahun 2014 tentang Desa, pemerintah desa hadir sebagai representasi mandat konstitusi itu. Desa ditetapkan empat kewenangan yakni menyelenggarakan, membangun, memberdayakan, dan membina masyarakat desa. Artinya pemerintah desa berhak untuk mengatur dan mengurus bagian dari hak dan kewenangan desa dan kewenangan lokal berskala desa (baca UU No 6/2014 tentang Desa) termasuk mengelola sumber daya milik bersama (common pool resaurces/CPR).

Namun dalam realitasnya kewenangan desa untuk mengatur dan mengurus tidak berjalan sesuai dengan kehendak UU Desa. Hal ini terjadi karena wajah ganda pembangunan (Refi \& Falahi, 2014). Pada satu sisi pembangunan membawa niat baik untuk menanggulangi kemiskinan. Pada saat yang sama malah melahirkan konflik di desa. Praktik semacam ini terjadi pada program desa wisata di Desa Pacarejo. Program mensyaratkan pengelolaan wisata Telaga Jonge ditangan Pokdarwis. Karakteristik ini menempatkan komunitas sebagai pengelola sekaligus pengurus wisata Telaga Jonge. Sementara pemerintah desa sebagai representasi konstitusi dan rakyat desa malah diabaikan.

Praktik dan tindakan program menempatkan Telaga Jonge berjalan picang. Pokdarwis beroperasi di desa sekaligus mengunakan sumber daya milik desa. Tetapi tidak melibatkan desa. Desa hanya dijadikan sebagai fasilitator program. Padahal semua aktivitas wisata mengunakan fasilitas publik desa. Pokdarwis malah tumbuh secara otonom di bawah kendali Dinas Pariwisata. Sturuktur birokrasi Pokdarwis 
mempertegaskan pengalihan kebermanfaatan Telaga Jonge bukan untuk desa tetapi dikendalikan supradesa melalui program desa wisata. Pada konteks ini desa tidak mendapatkan apa-apa tetapi desa dan rakyatnya menikmati volusi dari desa wisata.

Abai terhadap desa berbuntut pada privatisasi. Hal ini jelas membuat tanah personal dan tanah milik bersama tidak bisa berjalan secara beriringan. Padahal wisata Telaga Jonge belum berkontribusi terhadap Pendapatan Asli Daerah dan Pendapatan Asli Desa. Tetapi konflik antara pemerintah desa, masyarakat dan Pokdarwis sudah memuncak berupa abai terhadap Perdes, pengaturan hak dan akses masyarakat oleh Pokdarwis, mengabaikan pemerintah desa dari arena wisata Telaga Jonge. Terlebih masyarakat dan kelompok tidak mampu menegosiasikan akses atas telaga. Bahkan praktik dan tindakan Pokdarwis bersifat ekslusif.

Pijakan itu kemudian menjadi basis permasalahan pokok yang dibimbing mengunakan dua pertanyaan penelitian untuk menguji sekaligus melahirkan pengetahuan baru dalam tata kelola CPR. Pertama, mengapa terjadi perubahan status CPR menjadi milik privat? bagaimana pemerintah desa menyikapi perubahan status CPR? Penelitian ini bertujuan untuk menguraikan kegagalan Pokdarwis/pradingma pembangunan berbasis masyarakat dalam mengelola CPR dan menemukan cara kerja pemerintah desa dalam menyikapi kegagalan itu, sekaligus mengajak kita agar tidak latah dalam menempatkan Pokdarwis sebagai mengelola CPR.

\section{THE COMMON DAN INSTITUSI PENGELOLA}

Konsep barang milik bersama/commons pool resaurces (CPR) harus dipahami sebagai sub bagian dari barang-barang publik. Barang dapat dikatakan sumber daya milik bersama apabila memenuhi keterbatasan atau subtraktif dalam konteks barang publik. Misalnya analogi Wade jika A menggunakan lebih banyak, lebih sedikit sisa untuk yang lain (Wade 1997). Apabila pengunaan CPR tidak di-atur dan dikelola secara bersama rentan membawa konflik. Pada konteks ini CPR biasanya berpotensi mengalami kemacetan, penipisan, atau degradasi, yaitu penggunaan yang didorong melampaui batas hasil yang berkelanjutan (Blomquist dan Ostrom, 1985; Randall, 1983 dikutip dari Wade, 1987). Garet Hardin menjelaskan tragedi bersama terjadi akibat dari absenya hak kepemilikan dan otoritas yang tinggi mengakibatkan over ekploitasi. Oleh karena itu lebih baik diprivatisasi atau diserahkan kepada tangan negara (Hardin, 1968). Berbeda, Elinor Ostrom (1990) mengajukan term (CPR) dikelola komunitas untuk menghindari tragedi bersama. 
Konsep institusi pengelola CPR disini mengacu pada institusi formal versus institusi alamiah di desa. Dua padangan ini memunculkan perdebatan antara yang substansial dan normatif (Nugroho, AAGN Ari Dwipayana, et al., 2017). Pandangan normatif berpijak pada status formal. Heywood (2013) mendefenisikan institusi merupakan sebuah badan yang kukuh dengan sebuah peran dan status formal; lebih luas, serangkaian aturan yang menjamin perilaku yang teratur dan dapat diprediksi. Singkat kata, institusi mempegaruhi masyarakat bukan masyarakat mempegaruhi institusi. Sementara Hodgson mendefenisikan institusi:

“...social rule-systems, not simply rules. Institutions are systems of established and embedded social rules that structure social interactions." Hodgson kemudian menambahkan bahwa institusi tidak hanya dilihat sebagai aturan atau norma maupun perilaku atau kebiasaan (habit) yang ada dalam diri seseorang, suatu organisasi, dan entitas lainnya. Namun, institusi juga merupakan suatu sistem yang sudah mapan dimana aturan-aturan sosial yang tertanam turut memengaruhi interaksi sosial (Nugroho, et al. 2017).

Pandangan alamiah ini menempatkan realitas mempegaruhi institusi. Karakteristik institusi semacam ini tumbuh secara alamiah. Biasanya berpijak pada kepentingan bersama dengan mengandalkan prakarsa lokal. Norma, aturan, dan desain kelembagaan dibentuk berdasarkan kearifan lokal dan kebiasaan masyarakat setempat. Institusi ini cukup berhasil dalam mendistribusikan keadilan sebagaimana kelompok Penebas di Sulawesi (Chazali dikutip dari Nugroho, et al. 2017).

Ostrom dalam karyanya Governing The Commons; The Evolution of Institusion for Collective Actions berusaha menjembatani antara komunitas lokal, swasta, dan negara dalam mengelola CPR. Atas dasar itu Ostrom (1990) mengajukan delapan desain yang harus dipenuhi institusi untuk mengatur dan mengelola CPR agar efektif; Pertama, memperjelas identitas kelompok pengelola CPR. Kedua, manfaat dan biaya yang dikeluarkan, Ketiga, kepengaturan berpijak pada pilihan kolektif. Keempat, perlu ada pengawasan agar tidak terjadi pencurian dan eksploitasi. Kelima sanksi diawal berupa teguran kecuali melampaui batas. Keenam, mekanisme penyelesaian konflik harus ditempuh melalui cara yang dianggap adil. Ketujuh, perlu ada pengakuan atas hak berorganisasi. Kedelapan, untuk kelompok yang lebih besar harus ada koordinasi yang tepat antara kelompok yang dianggap relevan. Ostrom menekankan pada komunitas lokal homogen. 
Dalam tataran realitas konsep kolaborasi institusi Ostrom diterjemahkan menjadi pradigma pembangunan berbasis masyarakat/community driven development. Sebagaimana diterapkan melalui Program Nasional Pemberdayaan Masyarakat / PNPM Mandiri (Carroll, 2012). Secara khusus PNPM mengorientasikan komunitas sebagai pengelola dana program di desa. Tetapi konsep komunitas ini mengalami permasalahan ketika diterjemahkan ke dalam kebijakan. Saunders (2014) teori CPR milik Ostrom mengalami penyederhanaan dari kelembagaan lokal menjadi kelembagaan formal dalam proyek bersama. Proyek-proyek milik bersama, seperti manajemen sumber daya alam berbasis masyarakat merupakan adaptasi yang disederhanakan oleh beberapa organisasi non-pemerintah dan lembaga-lembaga pembangunan tentang penerimaan yang meluas dan janji untuk memberikan kontrol sumber daya kepada kelompok-kelompok dan individu-individu tergantung pada mereka demikian lanjut Saunders. Mengikuti Carroll (2012) Program seperti PKK dan PNPM mengunakan ideologi yang sama dengan mekanime yang berbeda. Model program ini lahir sebagai bentuk revisi atas pembangunan perdesaan terpadu/integerated rural development yang digerakan oleh negara (state led) dan kemudian dipakai oleh pemerintah Indonesia dalam PNPM mandiri (Eko, ed al., 2017)

Pada konteks ini PNPM hanya meminjam konsep identitas, partisipasi dan homogenitas kelompok tanpa mengunakan secara penuh. Hal inilah yang digunakan untuk merumus program desa wisata berupa kelompok sadar wisata. Pokdarwis bertugas untuk mengelola dan mengrus program di desa termasuk CPR. Walaupun membawa nama desa wisata tetapi tidak seperti village driven development/desa membangun, melainkan hanya kreasi yang menempatkan desa sebagai pemerintah semu Eko et al. (2017). Maka yang dihadirkan program adalah kelembagaan formal secara ad hoc seperti Pokdarwis. Meminjam istilah Peluso (2006) kelompok kemudian diilmiahkan agar mudah dihitung oleh program.

Sementara Robert Wade (1987) mengajukan CPR lebih baik dikelola dengan aksi kolektif desa. Aksi kolektif merupakan institusi yang menyebar kemudian menyatukan diri dengan membentuk dewan desa. Institusi ini muncul atas dasar kebutuhan dan kepentingan bersama untuk menyediakan barang milik bersama tanpa intervensi negara. Dalam cacatan kaki Wade (1987) menulis dewan desa sepenuhnya dibentuk oleh penduduk desa untuk diri mereka sendiri dan tidak mendapatkan otoritas dari negara. Desa menjadi institusi pengatur, mengurus, dan mengelola CPR untuk kebaikan bersama. Wasisto (2015) menegaskan kepengaturan memang lahir dari komunitas adat lokal. Hak 
asal-usul tersebut bersinggungan dengan akses pertama kali masyarakat dalam memanfaatkan sumber daya alam (Wade 1987 dikutip Wasisto 2015). Kasus-kasus yang berhasil dari sistem aturan yang dirancang secara lokal menunjukkan bahwa tidak perlu aturan dari luar (McKean, 1984; Ostrom, 1986 dikutip Wade, 1987). Pada konteks ini penghargaan terhadap otoritas lokal dan struktur sosial merupakan nilai terpenting untuk membentuk institusi yang melampaui komunitas, dusun, pluralisme yang diikat oleh otoritas desa bernama kolektivisme pluralistik (Geertz, 2000).

Keberhasilan ini ditunjukan Wade (1987) melalui studinya di desa-desa di India. Institusi yang berhasil jauh dari intervensi negara dan organisasi yang rumit tetapi mengandalkan kerjasama antar penduduk desa sesuai dengan konteks desa. Otoritas pengelola CPR berada di tangan dewan desa bertugas mengatur, mengurus, dan mengelola CPR. Seperti dikatakan McKean dikutip Wade (1987) menginternalisasi pelestarian commons (irigasi, kanal) sebagai tujuan vital. Pertama, tingkat konstitusional, orang dapat bernegosiasi secara sukarela seperangkat aturan akses terkendali atau kontribusi finansial, insentif mereka untuk melakukan hal itu sebagai keuntungan bersama yang prospektif. Kedua, Pada tingkat tindakan, sebagian besar kepatuhan terhadap peraturan juga harus bersifat sukarela, bukan hasil dari kalkulasi penghindaran dan hukuman. Tetapi aturan harus didukung oleh sistem hukuman, yang keberadaannya membantu meyakinkan setiap orang bahwa jika dia mengikuti aturan, dia tidak akan dihisap, dan yang pada saat krisis dapat langsung menghalang (Wade,1987).

\section{MENJELASKAN SENGKETA DAN MEMAHAMI SENGKETA}

Kehadiran sengketa di desa wisata Telaga Jonge Desa Pacarejo jelas berbeda dari tragedi bersama menurut konsep Garet Hardin. Sengketa bukan karena absenya institusi dan otoritas pengelola, tetapi karena, oleh dan dari kehadiran institusi itu sendiri. Kehadiran institusi seperti Pokdarwis membuat CPR berjalan pincang. Nalar dan tindakan Pokdarwis berpijak pada basis komunitas dan homogenitas sehingga mengabaikan desa dan makna CPR. Konsep kolaborasi institusi yang disampaikan Ostrom malah tidak relevan dan kontekstual ketika diterapkan di Desa Pacarejo. Hal ini terjadi karena konsep Ostrom hanya mengenal tradisi komunitas sehingga tidak relevan dengan derap nadi kehidupan desa. Sementara Wade menekankan pentingnya kehadiran desa sebagai cara untuk mengatur dan mengelola CPR di desa tanpa harus diintervensi oleh negara dan swasta. Berpijak pada bingkai teori tersebut ada beberapa argumen pokok untuk memahami sengketa. 
Pertama, sengketa bermula dari hadirnya program desa wisata yang mengorientasikan Pokdarwis sebagai pengelola dan pengurus CPR. Kedua, terjadi perubahan makna CPR dibawah kuasa Pokdarwis menjadi milik privat. Ketiga, praktik dan tindakan Pokdarwis melahirkan koflik vertikal dan konflik horizontal di desa. Jelas jalur ini akan mengerus struktur sosial dan otoritas lokal desa. Kelima, pemerintah desa berusaha mengembalikan CPR menuju kepemilikan desa

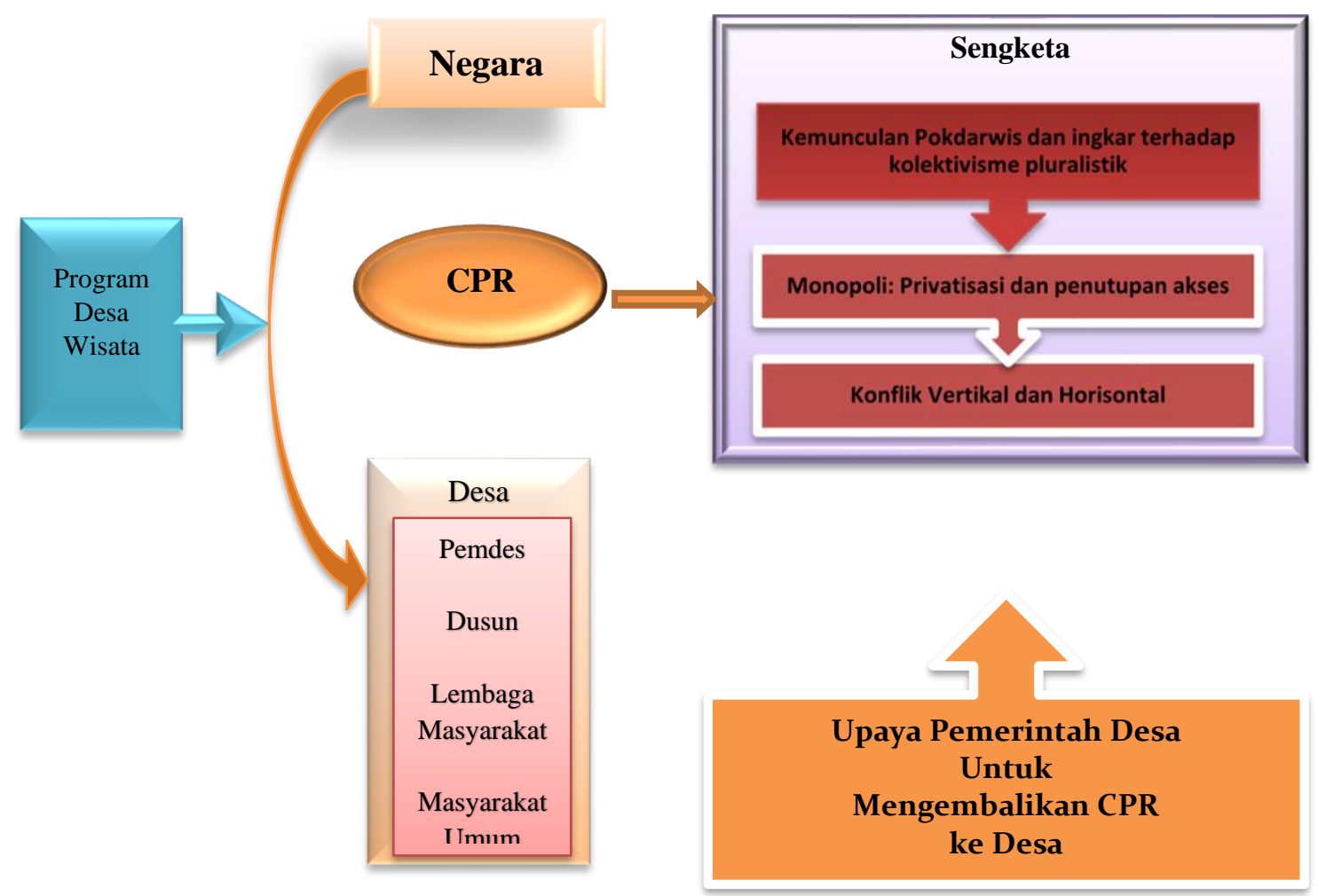

Gambar 1. Proses Tragedi dan Upaya Pemerintah Memproteksi Telaga Jonge.

\section{METODE PENELITIAN}

Penelitian ini dilaksanakan dari Februari - November 2020 di desa wisata Telaga Jonge Desa Pacarejo, Semanu Gunungkidul. Penelitian mengunakan pendekatan kualitatif dengan strategi studi kasus. Pilihan studi kasus memiliki kelebihan dalam mengeksplor kompleksitas realitas sosial yang dihadapkan subjek. Singkatnya tujuan menyempurnakan atau merintis pengetahuan baru (Abisono, 2020). Sebelum melakukan studi lapangan penulis berusaha memanfaatkan buku, jurnal dan media online. Referensi tersebut dipergunakan penulis untuk menyusun kerangka teoritis dalam menghasilkan kerangka pikir penelitian. Pada akhirnya menghasilkan argumen dan jalur untuk 
menjelaskan alur dan peta sengketa di desa wisata Telaga Jonge Pacarejo, kemudian dipandu mengunakan observasi, wawancara, dokumentasi, dan foto.

Pertama, observasi tak berstruktur. Secara khusus penulis melakukan observasi secara umum di wilayah Desa Pacarejo. Karena pada bulan Juli-September 2019 penulis melakukan Kuliah Kerja Nyata. Oleh karena itu, ketika melakukan penelitian penulis fokus melakukan observasi di wilayah objek wisata Telaga Jonge, posisi bangunan, hubungan pengelola dengan pemerintah desa dan masyarakat, tindakan masyarakat setempat, hubungan antar padukuhan, dan hubungan masyarakat setempat.

Kedua, wawancara mengunakan wawancara semi terstruktur. Teknik semacam ini ditempuh melalui tatap muka dengan cara membuat janji terlebih dahulu dan tempat yang terkondisikan secara baik di rumah informan atau di tempat yang sepi. Selama di lapangan penulis mengunakan alat bantu berupa alat tulis, recorder, panduan wawancara dan dokumentasi. Langkah ini dilakukan agar hasil wawancara terdokumentasi secara baik. Penulis mewawancarai di antaranya kepala desa, mantan kepala desa, perangkat desa (9 orang), Juru Kunci Telaga Jonge, Anggota Pokdarwis (5 orang), masyarakat sekitar Telaga Jonge ( 2 orang) dan Pelaku Usaha Objek wisata Telaga Jonge (3 orang).

Data lapangan kemudian dipandu dengan teknik analisis Miles dan Huberman dalam Sugiyono (2017) analisis data dilakukan pada saat pengumpulan data berlangsung, dan setelah selesai pengumpulan data dalam periode tertentu. Pada saat wawancara, peneliti sudah melakukan analisis terhadap jawaban yang diwawancarai setelah dianalisis terasa belum memuaskan, maka peneliti akan melanjut pertanyaan lagi sampai tahap tertentu, diperoleh data yang dianggap kredibel (Sugiyono, 2017: 132). Miles dan Habermen dikutip (Sugiyono, 2017) Proses analisis data ini dilakukan secara interaktif yang berlangsung secara terus menerus sampai tuntas hingga data tersebut sampai jenuh. Setelah selesai melakukan tugas itu berikutnya penulis melakukan interprestasi berdasarkan sajian data-data secara kontekstual dan sistematis untuk menghasilkan temuan-temuan baru atas praktik dan tindakan Pokdarwis dalam mengelola wisata Telaga Jonge. Pada akhirnya menghasilkan suatu abstraksi dari data tersebut.

\section{KONTEKS LOKAL DESA}

Desa Pacarejo merupakan satu diantara lima desa yang berada di wilayah Kecamatan Semanu, Kabupaten Gunungkidul DIY. Pacarejo memiliki luas 3074,31 hektar atau 28, $38 \%$ dari total luas Kecamatan Semanu, terbagi menjadi 28 padukuhan dan 28 Rukun Warga dan 140 Rukun Tetangga. Luas wilayah tersebut menempatkan 
Desa Pacarejo sebagai desa terluas sekaligus memiliki padukuhan terbanyak di Kabupaten Gunugkidul (BPS Kabupaten Gunungkidul, Kecamatan Semanu dalam Angka, 2020). Secara administratif Desa Pacarejo terletak di sebelah Selatan Kota Wonosari. Jarak pusat kota Wonosari dengan kantor pemerintahan Desa Pacarejo 7kilometer sementara jarak dengan Kantor Kecamatan 4 kilometer. Sebelah barat Pacarejo merupakan jalan antar kecamatan menghubungkan pusat kota degan Kecamatan Tanjungsari. Sebelah Timur terdapat jalan penghubung antara Kecamatan Semanu dengan Kecamatan Tepus. Jalur tersebut merupakan jalan menghubung menuju daerah pantai selatan. Sementara sebelah Utara merupakan jalan penghubung antar kabupaten. Desa Pacarejo persis berada di tengah. Singkat kata, pacarejo berada pada posisi strategis sentral menuju wisata pantai selatan.

Lenskap geografis Desa Pacarejo memiliki hamparan melandai. Kondisi tanah didominasi tanah latosol dan mediteran merah serta batuan induk batu cadas dengan wilayah bergelombang perbukitan. Curah Hujan Desa Pacarejo terbilang rendah. Tercatat rata-rata curah hujan pada tahun 2014 sebesar $1382 \mathrm{~mm}$ dengan jumlah hari hujan ratarata 89 hari pertahun atau 4-5 bulan basah. Sementara bulan kering berkisar 7 - 8 bulan. Intensitas bulan kering ini menyebabkan tanah pacarejo mengalami retakan-retakan manakala memasuki musim kemarau. Tipoliogi geografis itu menempatkan wilayah perbukitan dipenuhi dengan tanaman keras seperti kayu jati.

Terkait kondisi tersebut, pemerintah desa berusaha membangun embung bekerjasama dengan para pihak untuk mengantisipasi musim kering. Tercatat Pacarejo memiliki 13 telaga tersebar di 28 padukuhan. Daya tampung air hanya bertahan 4 bulan, kecuali Telaga Jonge. Selain itu, embung tidak disertai dengan teknologi penangkap air untuk petani. Singkat kata tidak dimaksimalkan untuk menopang lahan pertanian. Hal tersebut mendorong pemerintah desa dan masyarakat setempat untuk mengalih fungsi telaga mejadi unit wisata alam. Seperti Telaga Jowinantang dan Telaga Jonge.

Terkait demografis Desa Pacarejo hingga tahun 2019 berjumlah 16.415 jiwa lakilaki 8.001 jiwa dan perempuan 8.414 jiwa yang terbagi menjadi 4.818 kepala keluarga. Desa Pacarejo didominasi oleh usia produktif dengan angka 59,9 jiwa. Dominasi usia produktif juga menunjukan rasio ketergantungan masih rendah. Tetapi bonus demografi itu disertai dengan rasio ketergantungan mencapai $40 \%$ dari total penduduk. Masingmasing usia sekolah 21,6\%, usia lanjut 18,5\%. Hal ini berkorelasi negatif dengan tingkat pendidikan, terhitung $12 \%$ belum tamat SD, $26 \%$ Tamat SLTP dan tamat SD hampir 50 $\%$ dari total keseluruhan. Sementara SLTA diangka 12\%, perguruan tingggi $2 \%$, terhitung 
dari diploma D. I hingga Pasca Sarjana S2 (Perdes Pacarejo No 5 Tahun 2016 Tentang RPJMDes 2016-2021).

Selanjutnya, kondisi sosial masyarakat Desa Pacarejo masih berpegang erat dengan adat, tradisi lokal, kebersamaan dan kehidupan komunitas. Hal ini ditopang dengan kebiasan hidup berkelompok (komunitas pemuda, dusun, gotong royong, PKK, Karang Taruna, Poktan, Poknak). Dalam literatur dikenal dengan modal sosial yang bertujuan untuk menyelamat kelompok. Nilai-nilai ini tersemai melalui kegiatan kemasyarakatan dan kegiatan kemasyarakatan lain (Hasil observasi 2019-2020).

Kondisi ekonomi masih mengandalkan sektor pertanian dan sektor swasta. Tercatat $50 \%$ warga masyarakat berprofesi sebagai petani, $22 \%$ swasta. Sementara sektor lain masih berkisar pada angka yang sangat rendah (Buku Monografi Desa Tahun 2019). Terkait Pembangunan, mengikuti jalur strategis posisi desa yang terbagi menjadi tiga zona. Zona pertama, bagian Selatan Kantor Pemerintahan Desa Pacarejo diprioritaskan untuk pengembangan industri dan investasi masuk desa tepatnya di Padukuhan Tonggor. Zona kedua, Bagian Utara kantor Desa Pacarejo diprioritaskan untuk pembangunan fasilitas pendidikan dan sektor jasa. Zona tiga, bagian Timur Kantor Desa Pacarejo. Mulai dari padukuhan Jetis sampai padukuhan Nagampo diprioritaskan untuk pengembangan sektor wisata alam. Hingga saat ini sektor wisata membentang dari Timur menuju Barat: Wisata Kali Suci, Wisata Goa Jomblang, Wisata Telaga Jonge dan Wisata Bendung Jowinantang. Telaga Jonge persis berada di antara wisata lainya atau posisi strategis penghubung tiga zona tersebut.

\section{PEMBENTUKAN IDENTITAS}

Perkembangan pembentukan wisata Telaga Jonge tidak dapat dilepaskan dari dorongan program PNPM Perdesaan. Perkembangan dimulai semenjak generasi wisata alam Kali Suci dan Goa Jomblang. Terutama pengelolaan CPR di Desa Pacarejo semenjak 2009 silam dengan misi menanggulangi kemiskinan. Program PNPM Perdesaan membawa manajemen pengelolaan sumber daya alam berupa Desa Wisata yang mengorientasikan Pokdarwis. Meminjam istilah Peluso (2006) kehadiran manajemen sumber daya alam merupakan proses untuk pengilmiahkan CPR melalui administrasi berupa kebijakan, regulasi, program, dan birokratisasi di Telaga Jonge.

Tindakan dan praktik Pokdarwis dipandu mengunakan aturan yang telah ditetapkan oleh Kementrian Pariwisata. Pada konteks ini program desa wisata diluncurkan melalui PNPM Pariwisata merupakan representasi pengilmiah Telaga Jonge didorong melalui 
Instruksi Presiden Nomor 6 Tahun 2005 Tentang Kebijakan Pembangunan Kebudayaan dan Pariwisata, kemudian melahirkan Peraturan Pemerintah Kabupaten Gunungkidul Nomor 3 Tahun 2014 Tentang Rencana Induk Pembangunan Kepariwisataan Daerah Kabupaten Gunungkidul Tahun 2014-2025. Untuk menyelenggarakan peraturan pemerintah itu, Pemerintah Kabupaten Gunungkidul telah menetapkan Petunjuk Pelaksanaan atas Peraturan Daerah Kabupaten Gunungkidul Nomor 5 Tahun 2013 Tentang Penyelenggaraan Kepariwisataan yang memuat aturan tentang penetapan desa wisata dan desa budaya. Aturan ini juga menetapkan syarat bahwa desa budaya dan desa wisata wajib membentuk lembaga pengelola wisata bernama Pokdarwis sebagai pengelola wisata alam yang dilegalkan melalui Surat Keputusan Kepala Desa dan Surat Keputusan Dinas Pariwisata Kabupaten Gunungkidul. Kehendak program tersebut menempatkan pengelola objek wisata di desa harus bersifat formal dan mengacu pada Perda Kabupaten Gunungkidul. Padahal di tahun yang sama telah lahir Undang-Undang Nomor 6 Tahun 2014 tentang Desa yang meletakan asas rekognisi dan subsidiaritas dengan empat kewenangan kepada desa. Secara historis pengelolaan Telaga Jonge dapat dipaparkan dalam Tabel 1.

Tabel 1. Institusi Pengelola Jonge dari Tahun ke Tahun

\begin{tabular}{|c|c|c|c|}
\hline Tahun & Institusi & Sistem Pengelolaan & Manfaat \\
\hline$<2000$ & $\begin{array}{ll}\text { - } & \text { Tidak ada institusi } \\
\text { - } & \text { Tahun } 1992-1997 \\
\text { Komunitas Jonge } \\
\text { Raya. } \\
\text { - Komunitas Adat dan } \\
\text { Budaya Letari }\end{array}$ & $\begin{array}{ll}\text { - } & \text { Tidak ada } \\
\text { - } & \text { Berbasis kearifan } \\
& \text { lokal: aturan main, } \\
& \text { rekruitmen, dan } \\
& \text { kelembagaan. } \\
\text { - } & \text { Melestarikan Jonge }\end{array}$ & $\begin{array}{l}\text { - Untuk umum: mandi, } \\
\text { sumber air minum, } \\
\text { mandikan ternak, ritual } \\
\text { adat, untuk pertanian. } \\
\text { - Untuk membudidaya } \\
\text { ikan, tepat pemancingan, } \\
\text { mandi umum dan } \\
\text { pertanian. } \\
\text { Melstarikan adat di } \\
\text { Telaga Jonge } \\
\end{array}$ \\
\hline $\begin{array}{ll}2001 & - \\
2010 & \end{array}$ & $\begin{array}{l}\text { - Kelompok Masyarakat } \\
\text { - Komunitas Adat dan } \\
\text { Budaya Letari }\end{array}$ & $\begin{array}{ll}\text { - } & \text { Tidak ada } \\
\text { - } & \text { Berbasis: } \\
& \text { Melestarikan warisan } \\
& \text { leluhur } \\
\end{array}$ & $\begin{array}{l}\text { - Untuk ritual adat, mandi, } \\
\text { mencuci, pertanian. } \\
\text { - Melestarikan adat di } \\
\text { Telaga Jonge }\end{array}$ \\
\hline 2011> & $\begin{array}{ll}\text { - } & \text { Komunitas Adat dan } \\
\text { Budaya Lestari } \\
\text { - Komunitas pemuda - } \\
2014 \\
\text { - Komunitas } \\
\text { Panguyuban Pacarejo } \\
\text { Manunggal 2015 - } \\
2017 \\
\text { - Pokdarwis bentukan } \\
\text { program Desa Wisata } \\
\text { 2018- Sekarang }\end{array}$ & $\begin{array}{l}\text { - } \text { Tidak ada } \\
\text { - Berbasis kearifan lokal } \\
\text { - Berbasis komunitas } \\
\text { desa wisata: aturan } \\
\text { main, akses, anggota } \\
\text { dan aktivitas } \\
\text { ditentukan kelompok } \\
\text { Berbasis komunitas } \\
\text { mengacu pada aturan } \\
\text { program desa wisata }\end{array}$ & $\begin{array}{l}\text { Melestarikan adat di } \\
\text { Telaga Jonge } \\
\text { Telaga mulai dikelola } \\
\text { untuk aktivitas wisata } \\
\text { alam. } \\
\text { Jonge di kelola PPM } \\
\text { untuk aktivitas wisata } \\
\text { alam } \\
\text { Untuk aktivitas wisata } \\
\text { alam dan ekonomi } \\
\text { kreatif berbasis wisata. }\end{array}$ \\
\hline
\end{tabular}

Sumber: Dielaborasi berdasarkan hasil wawancara. 
Menurut Rencana Induk Pembangunan Kepariwisataan Kabupaten Gunungkidul 2014-2025 Telaga Jonge ditetapkan menjadi unggulan pembangunan wisata alam berbasis masyarakat. Hal ini tidak terlepas dari posisi strategis Telaga Jonge. Namun perkembangan wisata seperti Kali Suci dan Goa Jomblang menyeret Jonge menjadi wisata alam. Sistem pengelolaan diletakan pada komunitas berdasarkan PTO Program Desa Wisata.

Realitas pemerintah desa justru datang belakangan. Tetapi kehadiran aktor Suhadi (Kepala Desa) justru membawa misi desa wiata untuk pacarejo sehingga terbentuklah Panguyuban Pacarejo Manunggal (PPM) yang memiliki spirit sadar wisata. Keanggotaan terdiri dari seluruh pemuda Pacarejo (wawancara Muslam, 3 Maret 2020). Namun semangat ini bertentangan dengan pengelola wisata terdahulu. Atas dasar komunitas Pokdarwis kemudian komunitas alamiah malah diabaikan. Hal ini tidak terlepas dari dinasti kelompok yang tumbuh lebih dahulu. Pada saat yang sama malah memicu terjadinya konflik antar komunitas dan Padukuhan setempat. "Kami tidak rela kalau Telaga Jonge itu di kelola PPM, karena itu berada di wilayah kami" (wawancara Mursono, 2 Maret 2020). Pengakuan atas hak milik menjadi basis argumentasi atas Telaga. Menurut Padukuhan Kuwangen kehadiran PPM dianggap melupakan sejarah kepemilikan Jonge secara geografis. Alhasil konflik dikelola melalui musyawarah bersama antar padukuhan, komunitas dan pemerintah desa diantaranya: Padukuhan Kuwangen Lor, Kidul, Padukuhan Jetis, Padukuhan Wilayu, Padukuhan Jonge, Padukuhan Jelok dan Padukuhan Jasem (berita acara pembentukan Pokdarwis, 15 Oktober 2018). Hasilnya adalah terbentuknya Pokdarwis Jonge Raya. Hal ini tidak terlepas dari dorongan Dinas Pariwisata Gunungkidul agar segera membentuk Pokdarwis (Wawancara Yudi, 5 Agustus 2020). Pokdarwis Jonge Raya kemudian dikukuhkan melalui Surat Keputusan Dinas Pariwisata Kabupaten Gunungkidul Nomor 002/KPTS/2019 Tentang Pengukuhan Kelompok Sadar Wisata Jonge Raya Desa Pacarejo Kecamatan Semanu Kabupaten Gunungkidul.

Kehadiran Pokdarwis Jonge raya tidak terlepas dari dorongan aktor kuat (penginisiasi, juru kunci, aktor penggerak wisata terdahulu, polisi dan aktor yang memiliki akses keluar). Aktor-aktor ini menjadi orang kunci dalam membawa gagasan wisata di Telaga Jonge yang dipandu mengunakan Program Desa wisata. Pengalaman dan kemampuan membangun akses inilah yang coba disuntikan di Telaga Jonge. Pokdarwis membawa asumsi pemerintah desa merupakan orang baru. Terlebih partisipasi dan kontribusi pemerintah desa sangat minim. Di sinilah letak kelemahan aksi kolektif yang 
cenderung mengorbankan pihak tidak rasional (Olson, 1971). Hadir belakangan juga menjadi masalah tersendiri bagi kepala desa dalam hal ini sebagai mandat rakyat yang dipillih melalui elektoral. Tetapi nalar Pokdarwis berusaha merebut hak dan akses melalui kontribusi, partisipasi, tenaga, pikiran dan juga perawatan. Hal ini dijadikan untuk mengabaikan desa yang selama ini tidak memberikan sumbangan yang berarti terhadap pembangunan wisata Jonge menurut Pokdarwis. Tindakan dan praktik Pokdarwis hanya berpijak pada komunitas sesuai kehendak program. Cara pandang ini menempatkan desa sebagai masyarakat tanpa pemerintah dan pemerintahan (Eko, 2015: 20).

Realitas itu membuat Pokdarwis tumbuh secara otonom dan paling berhak atas CPR. Sementara pihak desa dan masyarakat malah diabaikan. Tetapi kuasa Pokdarwis tidak berlaku secara universal malainkan untuk melawan desa dan masyarakat setempat. Tetapi dihadapan supradesa Pokdarwis malah tunduk dan tidak mampu bernegosiasi. "Kami lebih memilih Dinas Parwisata dari pada desa" (wawancara Budiraharja, 8 Agustus 2020). Pilihan terhadap supradesa tidak terlepas dari kontribusi yang diberikan melalui uang program desa wisata dan bantuan lain yang diberikan. Kucuran dana program dan dana bantuan dari luar sekaligus mengokohkan posisi Pokdarwis yang berlindung dibalik desa wisata. Tetapi operasionalnya Pokdarwis berkuasa atas sumber daya di desa. Menguatnya komunitas merupakan bentuk baru kuasa program melalui birokrasi berupa Pokdarwis. Mengikuti Li (2012) Pokdarwis merupakan bentuk pemerintah komunitas di tataran desa yang dikendaki program.

\section{SENGKETA DAN DILEMA PENGELOLAAN TELAGA JONGE}

Semakin otonom Pokdarwis malah melahirkan konflik vertikal dan horizontal akibat dari menguatnya nalar komunitas yang meninggalkan desa. Konflik hadir sebagai respon terhadap tindakan dan praktik Pokdarwis. Hal ini terjadi karena pergeseran status kepemilikan Telaga Jonge menjadi milik privat. Jonge yang dibayangkan bebas seperti angin malah dikonversi menjadi milik privat. Pada saat yang sama, tanah milik personal tidak bisa berjalan secara beriringan. Di sini telah terjadi pergeseran makna bahwa "rezim kepemilikan" seperti yang dikatakan oleh Fauzi (2014) benar-banar menjelma bukan tanpa sebab, melainkan didorong dan digerakan program berbasis masyarakat melalui program "desa wisata" yang mengorientasikan Pokdarwis sebagai tulang punggung program. Padahal Pokdarwis hanya sebagai pengelola. Tetapi realitasnya menjelma menjadi penguasa d iatas tanah milik negara dan desa. Praktik dan tindakan ini membuat Pokdarwis tidak lebih sebagai oligarki di desa. Pada dasarnya mereka membangun dinasti 
kelompok melalui desa wisata, ucap Sutoro Eko pada saat penarikan mahasiswa KKN September, 2019 di Balai Desa Pacarejo. Praktik dan tindakan itu dibenarkan oleh Suhadi Kepala Desa Pacarejo.

Semakin menguatnya Pokdarwis malah menyingkirkan pemerintah desa dari Telaga Jonge. Padahal Pokdarwis memperoleh SK dari Kepala Desa, tetapi sisi lain Pokdarwis lebih memilih tunduk kepada Dinas Pariwisata atas kucuran dana dan bantuan yang diberikan. Sementara Kepala Desa sebagai mandat konstitusi dan rakyat desa malah tidak dilibatakan secara penuh. Kepala desa hanya ditugaskan untuk melegalisasi dan fasilitator program.

Hal serupa juga memicu terjadinya konflik antar kelompok dan masyarakat setempat serta melahirkan perlawanan kecil-kecilan. Ini terjadi karena tindakan Pokdarwis telah melampaui batas-batas ekonomi subsisten petani (Scott, 1981). "Itukan hak pengelolaan Kuwangen Lor dan Kidul itu kemaren nggak diajak anu musyawarah itu. Makanya terjadi konflik kayak gitu" (Wawancara Purwanto, 3 Maret 2020). Mengikuti postruktural mekanisme yang tidak demokratis tidak dapat dilihat sebagai ruang hampa. Absennya warga dan padukuhan lain merupakan ekspresi kuasa Pokdarwis. Menurut mereka kecemburuan sosial itu menjadi hal yang wajar antar sesama. Bahkan kecemburuan sosial itu dianggap tidak rasional.

Pokdarwis lupa bahwa kucuran dana pembangunan wisata terpusat. Dorongan inilah yang mengerakan warga setempat mengarahkan perhatian di Telaga Jonge. Sementara, spot-spot lainya tidak disediakan. Kalaupun disedikan objek itu malah dimonopoli oleh Pokdarwis. Hal serupa terjadi terjadi pada Goa Jomblang dan Kali Suci. Dua unit wisata itu tidak melibatkan desa secara penuh melainkan dikelola komunitas. "Saya itu susah kalau bersikeras malah desa tidak dapat apa-apa dari Goa Jomblang" (Wawancara dengan Suhadi 3 Maret 2020).

Rezim kepemilikan komunitas (Pokdarwis) menempatkan penduduk setempat tereksklusi. Masyarakat umum tidak bisa mengakses telaga secara bebas. Pokdarwis malah mengeksklusi untuk mendapat tanah pertanian yang terjadi diantara orang dekat, tetangga dan kerabat (Hall, et al. 2020: 36). Hal ini menjadi pemicu perubahan struktur sosial masyarakat. "Mereka malah tidak mau tau lagi dengan masyarakat, apalagi masyarakat udah cukup sana ada disini tidak" (wawancara Kriswanto, 29 Februari 2020). Tindakan semacam ini jelas menggerus kearifan lokal dan struktur sosial masyarakat yang berujung pada kecemburuan sosial dan hilangnya kepercayaan. Padahal niat program melalui Pokdarwis untuk memperkuat nilai kepercayaan tetapi realitasnya 
malah mengabaikan hal tersebut. Maka tidak heran praktik itu memicu terjadi perlawanan secara tertutup. Masyarakat yang dirugikan berusaha membangun narasi yang bertujuan untuk merusak nama baik dan bertindak ngeyel. Seperti yang dilakukan oleh dua orang pedagang asal Padukuhan Jonge, tidak banyak bicara tetapi memperoleh hasil dagangan. Atas dasar itu kedua pedagang mengalami perlakukan tidak adil.

Realitas tersebut membuat masyarakat dan pedukuhan sekitar tidak mau melibatkan diri. Walaupun keberadaan Telaga Jonge berbatasan langsung dengan padukuhan mereka. "Padukuhan Wilayu tidak mau melibatkan diri kecuali Ketua Karang Taruna, (wawancara Ngatio, 2 Maret 2020). Memilih pasrah lebih baik dari pada merebut tetapi berpotensi konflik. Hal ini menandakan mereka sudah sering berhadapan dengan situasi serupa. "besok masuk neraka karena tidak berbuat senonoh" (wawancara Tini, 29 Februari 2020). Mengikuti Scott (2000) bahwa konteks perlawanan itu merupakan sejatanya orang-orang yang kalah atau dalam porsi yang lain perlawanan di simpang jalan konteks harian di desa-desa sekitar hutan (Santoso,2004). Meminjam istilah Scott senjatanya orang-orang kalah justru menjadi basis perlawanan yang efektif untuk memperoleh manfaat dari kepemilikan bersama.

\section{UPAYA PEMERINTAH DESA UNTUK MENGEMBALIKAN TELAGA JONGE}

Mengikuti Robert Wade bahwa di sini perlu menghadirkan otoritas desa yang dipiih oleh masyarakat. Pada konteks ini kepala desa merupakan representasi masyarakat untuk mengatur, mengurus, dan mengelola desanya termasuk sumber daya alam yang ada di desa. Pijakan itu digunakan kepala desa untuk menghadirkan pemerintah desa melalui rekayasa sosial sesuai dengan konteks desa. Ketika ditanya perihal Jonge Kepala Desa menjawab "kalau kemudian kita sama-sama keras itu tidak akan ketemu. Tapi saya sebagai orang tua berkewajiban mengambil celah-celah supaya teman-teman itu bisa mengerti tujuan, maksut dan manfaat pemerintah desa itu sendiri. Tapi apa sebenarnya ini saya betul betul konsen Jonge menjadi pionir untuk contoh pengembangan potensi berdaya atau laboratorium desa wisata” (wawancara Suhadi 03, November 2020).

Untuk sampai kepada hasil dan kesepakatan bersama pemerintah desa melakukan 4 stategi dalam mengelola konflik dan memproteksi CPR ke dalam desa. Pertama, berusaha melakukan pendekatan personal dengan aktor-aktor kunci. Pada konteks ini Kepala desa berusaha mendekatkan aktor-aktor kunci pengelola Jonge. Membangun persahabatan, mendekatkan dan merangkul pengelola untuk percaya pada pemerintah desa. "diskusi formal maupun nonformal itu jalan sekarang” (wawancara Muslam 3, 
Maret 2020). Ruang ini diamnfaatkan untuk merasionalkan keberadaan Jonge bukan dikuasai oleh kelompok. Karena pada dasarnya kemajuan suatu desa bukan membawa nama dusun atau kelompok tetapi membawa desa secara keseluruhan. Seperti yang terjadi sekarang walaupun pengelola membawa nama desa wisata tetapi realitas bukan desa yang mengelola melainkan kelompok yang dihendaki program. Praktik dan tindakan inilah yang disebut Ferguson (1990) bentuk dari ekspansi birokrasi di desa. Mereka tidak mementingkan hasil dan dampak, yang jelas kuasa dan kontrol politik semakin menguat. "Mindset kelompok itu selesaikan, mindset sekarang harus desa. Karena secara nasional bukan dukuh yang maju tetapi Desa Pacarejo yang maju” jelas Suhadi. Niat dan kehendak inilah yang terus ditebarkan oleh pemerintah desa untuk membangun kerjasama. Aktivitas ngobrol secara pribadi tentang desa terus dilakukan tanpa henti. Tetapi yang jelas pendekatan ini sesuai dengan kultur dan kebiasan masyarakat setempat. Atas dasar itu "pak kades itukan setidaknya mempegaruhi lebih banyak" (wawancara Sumadianto, 8 Agustus 2020).

Kedua, melalui pendekatan sosial. Pendekatan bekerja melalui ruang nonformal. Kepala Desa melakukan kunjungan langsung ke wisata dan melihat kondisi rill. Tindakan ini bertujuan untuk mengumpulkan informasi sekaligus membangun siasat terhadap pengelola melalui ngobrol bareng, naik perahu, kerja bersama. Hal ini dilakukan untuk memastikan informasi dan realitas pengelolaan sumber daya milik bersama. Mendekatkan pengelola dengan pemerintah desa. Terutama kepala desa merupakan orang baru. Kedekatan emosional sangat penting dihadirkan. Terlebih untuk melampaui tradisi komunitas yang cenderung rentan terhadap pengaruh ekternal. Dalam literatur karakteristik modal sosial ini disebut dengan sosial bonding. Jenis modal sosial ini cenderung eksklusif dan hanya untuk menyelamat ke dalam (Eko 2014). Oleh karena itu pendekatan personal sangat akrab dan sesuai dengan denyut nadi kehidupan masyarakat desa. "saya bagaimanapun juga sebenarnya kultur orang-orang pacarejo pada umumnya baik itu di padukuhan mana, sebenarnya itu dilakukan mengandalkan sisi kemanusiaan dan sosial. Intinya dalam aspek komunikasi kita wong desa langsung saja. Walaupun butuh sekian lama waktu, tapi lama-lama juga mulai sadar. Ini terus terang dilakukan dengan penuh ketelatenan untuk mengkondisikan teman-teman” jelas Suhadi. Singkatnya, kepala desa memahami betul karateristik masyarakat desa termasuk untuk mengelola Telaga Jonge. Realitas itulah kemudian yang mendorong kepala desa melakukan pendekatan sosial untuk percaya kepada pemerintah desa. Oleh karena itu, 
pemerintah desa dan kepala desa bertindak untuk memastikan pengelola CPR bukan di tangan kelompok tetapi harus dikembalikan ke desa.

Ketiga, pendekatan kemanusiaan dan pendekatan budaya. Pada konteks ini pemerintah desa berusaha membangun kepercayaan tanpa pandang bulu. Bahwa sebagai mandat rakyat dan dipercayakan oleh rakyat kehendak itu harus dijalankan untuk mencairkan suasana. Pendekatan ini ditempuh untuk mengiring pengelola bahwa kehadiran Pokdarwis bukan menguasai tetapi harus difasilitasi oleh desa. Hal ini tidak terlepas dari semua aktivitas wisata merusak barang publik desa, sehingga desa harus hadir. Pemerintah desa berusaha membangun komunikaasi yang dirasa retak akibat konflik vertikal dan horizontal. Peran komunikasi langsung dan melibatkan diri secara penuh dengan masyarakat dan pengelola menjadi sangat penting. Hal ini sekaligus untuk menghilangkan imajinasi dan persepsi pengelola tentang absenya pemerintah desa dari Telaga Jonge. "Datangi mereka dengan tatapan mata yang santai dan membawa senyum. Membangun komunikasi, kita datang bukan sebagai konteks lurah tetapi berusaha menjadi masyarakat biasa bepernampilan biasa" tutur Suhadi. Dalam tataran praktik direpresentasikan melalui acara-acara penting yang ditempatkan di Telaga Jonge dan acara kemasyarakatan di desa. Pada konteks ini "desa terlibat yah terlibat" (wawancara Mursono 3 November 2020). Bahkan kehadiran pemerintah desa justru sangat penting sebagai pihak yang bertanggungjawab atas kegiatan dan kemajuan desa. "Kita tidak bisa terlepas dari desa bagaimanapun juga kita membutuhkan" (wawancara Yudi, 8 Agustus 2020). Singkatnya pemerintah desa bertugas untuk memfasilitasi dan memberi rasa aman kepada masyarakat desa. Bukan membiarkan tetapi memberikan ruang.

Sebagai pemimpin rakyat kepala desa bertindak mengunakan rasa dan hati untuk menyambung keretakan komunikasi dan ketegangan dengan Pokdarwis. Bahkan rasa tindak malu dan masa bodoh malah mampu mencairkan ketegangan untuk menarik simpati pengelola. Setidaknya itulah jalur yang ditempuh kepala desa untuk meyakinkan kepada pengelola. "Kemanusiaan soal rasa tumpahkan saja. Sebagai lurah, orang tua itu tong sampah jadi tidak apa-apa silahkan mereka memandang kesini. Jadi pejabat politik itu memang konsekuenya seperti itu”, jelas Suhadi. Pemerintah desa justru berusaha menjadi pionir terhadap situasi desa dan masyarakatnya. Bahkan "sekarang sudah koling dan pak kades berhak" pungkas Purwanto salah satu pengelola.

Keempat, pendekatan politik. Di sini politik dipahami sebagai tindakan yang bijaksana bukan menghancurkan tetapi untuk memecahkan masalah. "Orang harus bijaksana, harus pandai-pandai menitip buih. Bukan suka atau tidak suka, tetapi 
manakala orang itu berbicara benar atau salah, itu akan luar biasa" tegas Suhadi. Kehadiran kepala desa jelas memberikan agin segar untuk mengelola konflik dan CPR melalui ruang politik. Bagaimanapun juga kepala desa dipilih berdasarkan hasil kesepakatan politik. Kesadaran akan nilai-nilai politik menempatkan ruang demokrasi menjadi sangat penting. Sebagai mandat rakyat yang memiliki otoritas pemerintah desa menempatkan kontestasi harian sebagai hal yang biasa untuk mewujudkan kebaikan bersama. Strategi ini bekerja melalui pembangunan di desa, bantuan masuk desa, media, ruang formal dan menghadirkan setiap kegiatan Pokdarwis termasuk mengarahkan kegiatan di Jonge. Tindakan semacam ini menjadi sebagai proses negosiasi. Meminjam istilah Aristoteles manusia adalah binatang politik. Dalam tataran operasional beguna untuk mewujudkan kebaikan bersama.

Begini pengakuan pengelola "Setelah ada pembangunan desa sudah terlibat. Mau tidak mau karena semua bantuan masuk ke Jonge itu melalui desa yang harus terlibat" ucap Juru Kunci. Menempatkan bantuan dan kegiatan di Jonge merupakan bentuk kehadiran pemerintah desa. Pemerintah desa bertanggungjawab untuk mengembangkan dan memajukan Jonge melalui kegiatan desa dan pembangunan agar ekonomi masyarakat bisa menggeliat. Termasuk mempromosikan dan memperkenalkan wisata Jonge kepada kalayak ramai. Bagaimana tidak pada saat lomba desa Kepala Desa menjadi garda terdepan. Bahkan hasil lomba desa wisata menempatkan Pacarejo sebagai juara lomba desa wisata Sekabupaten Gunungkidul (http://kalisuci.com/desa-wisata-pacarejo-juaralomba-desa-wisata-se gunungkidul-gtf-2020/).

Selanjutnya, pemerintah desa berusaha memanfaatkan ruang formal dan nonformal untuk memberikan sosialisasi dan pemahaman kepada Pokdarwis. Seperti kalimat "pandai menitip buih" sehingga Pemerintah Desa penting untuk menghadirkan semua kegiatan desa wisata. "Saya dalam semua kegiatan itu selalu hadir. Berusaha memanfaatkan celah kecil, termasuk acara kenduri. Berusaha memberikan masukan yang berhubugan dengan sistem pemerintahan desa" terang Suhadi. Singkatnya, menyesuaikan dengan kebudayaan dan kebiasaan masyarakat setempat. Di sini ia paham bahwa absennya pemerintah desa membuat kelompok semakin otonom seperti pengelola pendahulu. Tindakan semacam ini dilakukan berulang kali. Bahwa pemerintah desa bukan sebagai simbol tetapi sebagai mandat rakyat untuk menata wilayah dan masyarakatnya. Pemerintah Desa juga hadir dalam rapat dan pertemuaan-pertemuan, terutama terkait pembangunan wisata Telaga Jonge. 
Melalui mekanisme dan cara-cara inilah kemudian pemerintah desa memproteksi dan mengembalikan Jonge ke desa. Termasuk pemerintah desa juga terlibat dalam pengelolaan Jonge. Pemerintah desa yang dipandang sebelah mata justru menjadi aktor terpenting untuk kemajuan desa wisata. Alhasil konflik dan ketenggangan antara pengelola, masyarakat, dan pemerintah desa mampu dicairkan. Pemerintah desa hadir dan bekerjasama dengan dengan Pokdarwis. "Pemerintah yang sekarang juga sudah enak dan juga mendorong pembangunan Jonge" terang Purwanto. Buahnya membuat agenda bersama. Bahwa pemerintah desa bersama, BPD dan stakeholders segera menindaklanjuti Perdesa tentang Telaga Jonge (wawancara Suhadi, Yudi dan Juru Kunci 3, November 2020). Ini artinya pemerintah desa mampu meyakinkan aktor kuat dan pengelola. Pemerintah desa juga mampu memproteksi sengketa dan mendudukan ulang makna CPR. Realitasnya hari ini para pedagang memadati setiap sudut wilayah Telaga Jonge. Padahal sebelum ada kerjasama lokasi pedagang masih diatur (hasil observasi selama Kuliah Kerja Nyata Juli-September 2019). Tetapi setelah pemerintah desa mempu menyakinkan pengelola dan aktor kuat Jonge kembali pada marwah sebagai kepemilikan bersama. Atas dasar itu 7 padukuhan bisa mengakses secara bersama wisata Telaga Jonge (Wawancara Suhadi 3, November 2020, Muslam 29, Maret). Kehadiran pemerintah desa jelas memberikan agin segar terhadap masyarakat setepat. Telaga Jonge bisa dinikmati secara bersama oleh masyarakat Pacarejo bukan hanya komunitas pengelola. Hal ini sesuai dengan kehendak pasal 33 dan UU Desa.

\section{KESIMPULAN}

Pengelolaan CPR berbasis masyarakat (Pokdarwis) yang berpijak pada pemikiran Ostrom berusaha untuk menjadi jembatan antara negara, swasta dan lokal berupa program desa wisata. Namun, realitasnya praktik dan tindakan Pokdarwis malah menjelma menjadi penguasa CPR. Hal ini terjadi karena Pokdarwis meninggalkan desa. Praktik ini melahirkan privatisasi atas CPR. Buahnya konflik vertikal dan konflik horizontal. Tragedi Ini terjadi karena Pokdarwis bukan milik desa tetapi milik swasta yang dikendalikan melalui tekno-adminstratif melalui struktur birokrasi supradesa. Pemerintah desa dan masyarakat malah diabaikan. Realitas ini sekaligus mengatakan bahwa teori Garet Hardin tentang privatisasi CPR tidak relevan dan kontekstual ketika diterapkan di negara yang memiliki tradisi berdesa. Hak kepemilikan privat malah menyumbang tragedi baru berupa konflik juga terjadi di Telaga Jonge Desa Pacarejo. 
Hasil dan temuan dalam penelitian ini malah berbanding terbalik. Di tengah negara absen, pemerintah desa hadir untuk mendistribusikan CPR secara adil. Peran sentral pemerintah desa berusaha mematahkan nalar, tindakan swasta dan institusi berbasis masyarakat (Pokdarwis) yang melahirkan privatisi dan sengketa di Telaga Jonge. Pemerintah desa dan kepala desa sebagai mandat rakyat menempuh rekayasa sosial untuk meyakinkan pengelola dan mengakomodasi sengketa. Buahnya pemerintah desa mampu meyakinkan pengelola dan bekerjasama dengan pengelola. Hak kepemilikan CPR di kembalikan ke desa.

\section{REKOMENDASI}

Berpijak pada realitas tersebut Pertama, pengelolaan CPR harus memperhatikan konteks lokal desa melalui kesepakatan bersama desa. Hal ini mesti dilakukan karena CPR berada di desa bukan milik privat atau kelompok melainkan dikuasai negara sampai di desa di serahkan kepada desa untuk mengelola dan mengurus CPR bukan masyarakat. Kedua, kehadiran program desa wisata harus melibatkan desa secara penuh untuk memastikan peruntukan dan arah tujuan program. Terutama berkaitan dengan pengelola program sehingga tidak ingkar terhadap otoritas desa. Keempat, harus percaya kepada desa ini sesuai dengan dua asas yang diletakan pada UU Desa. Desa berhak untuk mengelola, membat aturan main, mengurus dan mendistribusikan keadilan kepada elemen masyarakat melalui pengelolaan CPR. Pada konteks ini negara bertugas mendistribusikan dan memproteksi.

\section{DAFTAR PUSTAKA}

Abisono F.G, Rini. T, Sakro A. 2020. The Commons Dalam Perspektif Kewargaan: Studi Konflik Pengelolaan Wisata Alam Desa Bleberan Gunungkidul. BHUMI: Jurnal Agraria dan Pertanahan Vol. 6 No. 1 Mei

Carroll, T. 2012. Kebijakan Pembangunan Neo-Liberal di Asia Pasca-Konsensus Wasington, Jakarta: INFID.

Eko S. M. Barori dan Hastowiyono. 2017. Desa Baru Negara Lama. Yogyakarta. Pascasarjana STPMD “APMD”.

Eko S. 2015. Regulasi Baru, Desa Baru: Ide, Misi, dan Semangat UU Desa. Kementrian Desa, Pembangunan Daerah Tertinggal dan Transmigrasi Republik Indonesia. Jakarta.

Fauzi A. 2010. Ekonomi Sumber Daya Alam dan Lingkungan: Teori dan Aplikasi. Cet ke-3. Gramedia Pustaka Utama. Jakarta. 
Geertz C. 2000. Negara Teater: Kerajaan-Kerjaan di Bali Abad ke Sembilan Belas. Yogyakarta. Yayasan Bentang Budaya.

Hal D, Hirsch P, \& Li M. T. 2020. Kuasa Eksklusi: Dilema Pertanahan di Asia Tenggara. Diterjemahkan Darmanto Simapaea dan Achmad Choirudin. Yogyakarta: INSISTPress.

Hardin G. 1968. Tregedy of The Commons. Jurnal Science Vol 162 No 3859

Heywood A. 2013. Politik. Yogyakarta: Pustaka Pelajar

Jati R W. 2015. Memaknai Masyarakat Sipil Sebagai The Commons: Transisi dan Aksi Dalam Tata Kelola Sumber Daya Alam. Jurnal BHUMI Vol. 1 No 2 : 117-122

Li Murray Tania. 2012. The Will To Improve: Perencanaan, Kekuasaan dan Pembangunan di Indonesia, Tangerang Selatan: Marjin Kiri.

Nugroho H, Dwipayana A. dkk. 2017. Potret Politik dan Ekonomi Lokal di Indonesia: Dinamika Demokratisasi, Pengembangan Ekonomi, dan Kawasan Perdesaan. Yogyakarta: Institute for Research and Empowerment (IRE).

Olson M. 1971. The Logic Of Collektive Aktion; Public Goods And The Theory Of Groups. London England: Harvard University Press.

Ostrom E. 1990. Governing The Commons; The Evolusion Of Instutions For Collektive Action. New York: Cambridge University Press.

Ostrom E. Gardener Rd dan Walker J. 1994. Rules, Games, and Common-Pool Resources. Michigan Press.

Peluso L. N. 2006. Hutan Kaya Rakyat Melarat; Penguasaan Sumberdaya dan Perlawanan di Jawa. Diterjemahkan Landung Simantupang. Yogyakarta. INSISTPress.

Publikasi Badan Pusat Statistik Kabupaten Gunungkidul: Kecamatan Semanu Dalam Angka 2020.

Santoso H. 2004. Perlawanan di Simpang Jalan: Kontes Harian di Desa-Desa Sekitar Hutan di Jawa. Yogyakarta. DAMAR.

Saunders P. F. 2014. The promise of common pool resource theory and the reality of commons projects. International Journal of the Commons Vol. 8, no 2 August: 636656.

Scott C J. 1981. Moral Ekonomi Petani: Pergolakan dan Subsistensi di Asia Tenggara. Yogyakarta: Yayasan Obor Indonesia.

Sorumali S. 2020. Upaya Pemerintah Desa dalam Pengembangan Desa Wisata di Desa Pacarejo.

Sugiyono. 2017. Metode Penelitian Kualitatif: untuk penelitian yang bersifat: eksploratif, enterpretif, interaktif dan konstruktif. Bandung: ALAFABETA. 
Wade R. 1997. Manajemen Sumber Daya Properti Bersama: Tindakan Kolektif Sebagai Alternatif Privatisasi Atau Peraturan Negara. Cambridge Journal of Economics 1987,11: 95-106.

Wicaksono W. K. 2012. Barang Publik dan Eksternalitas Pada Era Otonomi Daerah. Jurnal Bina Praja. Volume 4 No. 4 Desember: 281 - 286.

Wardana Agung. 2017. Neoloberalisasi Kawasan Perairan Teluk Banoa: Sebuah Catatan Kritis atas Praksis Perlawanan di Bali. Jurnal Transformasi Sosial. Vol No 35 Hal 55-90

2000. Senjatanya Orang-Orang Yang Kalah. Diterjemah Rahman Zainuddin, Sayogyo dan Mien Joebhaar. Jakarta: Yayasan Obor Indonesia.

Wawancara dengan Kriswanto, 29 Februari 2020

Wawancara dengan Tini, 29 Februari 2020

Wawancara dengan Mursono, 2 Maret 2020

Wawancara dengan Ngatio, 2 Maret 2020

Wawancara dengan Purwanto, 3 Maret 2020

Wawancara dengan Muslam, 3 Maret 2020

Wawancara dengan Yudi, 5 Agustus 2020

Wawancara dengan Sumadianto, 8 Agustus 2020

Wawancara dengan Budiraharja, 8 Agustus 2020

Wawancara dengan Suhadi, Yudi dan Juru Kunci 3, November 2020

Wawancara dengan Mursono 3 November 2020 